\title{
Sistem Pendukung Keputusan Menentukan Lovebird Unggul dalam Perlombaan Menggunakan Metode AHP-Topsis
}

\author{
Eka Larasati Amalia, Rudy Ariyanto, Asa Nara Pratama
}

\begin{abstract}
Indonesia Lovebird Community of Tuban Region is one of the communities to hold contest agenda, specifically on beauty and singing contest. However, the scoring process is performed manually, which may lead to a subjective assessment of the candidate and the difficulty in determining the scoring criteria in the form of a number. Thus, to solve these problems, Indonesia Lovebird Community of Tuban Region needs decision support systems (DSS) for determining excellent lovebird in the contest by adjusting the scoring and the criteria. The methods used are the Analytic Hierarchy Process (AHP) and Technique Order Preference by Similarity to Ideal Solution (TOPSIS). The application can ease the scoring and decision making process due to the support in the decision making. Furthermore, the candidate selection of this contest performed using this application provides accurate results as evidenced by the comparative testing between manual selection and system selection with an accuracy of $98 \%$.
\end{abstract}

Index Terms-Decision Support System, Lovebird Contest, AHP, TOPSIS

\begin{abstract}
Abstrak--Komunitas Lovebird Indonesia - Wilayah Tuban adalah salah satu komunitas yang tiap tahunnya memiliki agenda perlombaan Beauty dan Singing contest, tetapi proses penilaiannya masih dilakukan secara manual, sehingga tidak menutup kemungkinan pada saat pengambilan keputusan untuk menilai kandidat dilakukan secara subjektif. Selain itu terdapat kesulitan dalam menentukan pembobotan kriteria, sehingga sulit menentukan pembobotan dalam bentuk angka. Dari masalah tersebut, maka Komunitas Lovebird Indonesia Wilayah Tuban memerlukan sistem pendukung keputusan (SPK) yang dapat membantu menyelesaikan masalah tersebut. Sistem pendukung keputusan menentukan lovebird unggul dalam perlombaan ini diharapkan mampu membantu
\end{abstract}

Eka Larasati Amalia is with the Informatic Technology Departement of Polytechnic State of Malang ,Malang, Indonesia (email eka.larasati@polinema.ac.id)

Rudy Ariyanto is with the Informatic Technology Departement of Polytechnic State of Malang ,Malang, Indonesia (email ariyantorudy@gmail.com)

Asa Nara Pratama is with the Informatic Technology Departement of Polytechnic State of Malang ,Malang, Indonesia (email asa.nara07@gmail.com) memangatasi masalah dengan menyesuaikan bobot dan kriteria. Metode yang dignakan adalah metode Analytic Hierarchy Process (AHP) dan Technique Order Preference by Similarity To Ideal Solution (TOPSIS). Aplikasi ini dapat membuat proses penilaian dan pengambilan keputusan menjadi lebih murah karena adanya dukungan dalam pengambilan keputusan. Selain itu seleksi kandidat dalam perlombaan yang dilakukan dengan aplikasi ini dapat memberikan hasil cukup akurat, hal ini terbukti dengan pengujian yang telah dilakukan dari perbandingan seleksi manual dan seleksi sistem dengan keakuratan $98 \%$.

Kata Kunci- Sistem Pendukung Keputusan, Lovebird, AHP, TOPSIS

\section{PENDAHULUAN}

Komunitas Lovebird Indonesia-Wilayah Tuban merupakan sebuah komunitas yang di dalamnya berisi penghobi Lovebird dari segala kalangan yang khususnya wilayah Tuban yang memiliki tujuan untuk mengenalkan kepada masyarakat secara luas. Selama ini Lovebird sangat dikenal di masyarakat dan sebagai peluang usaha. Disamping memberikan pengenalan kepada masyarakat Komunitas Lovebird Indonesia-Wilayah Tuban (KLI-WT) juga memberikan edukasi seputar budidaya, perawatan, dan pengobatan kepada anggotanya. Tak lepas dari itu, Komunitas Lovebird Indonesia Wilayah - Tuban (KLI-WT) setiap tahunnya mengadakan Anniversary. Pada Anniversary Komunitas Lovebird Indonesia Wilayah-Tuban (KLI-WT) mengadakan perlombaan seputar Lovebird diantaranya adalah Beauty Contest dan Singing Contest.

Dalam sistem perlombaan tersebut KLI-WT masih dilakukan secara manual, yakni juri harus menggunakan selembar kertas untuk melakukan penilaian. Setelah dilakukan penilaian, juri melakukan penjumlahan nilai setiap peserta. Dalam proses penjumlahan nilai, juri membutuhkan jeda waktu untuk menjumlahkan poin dan menentukan pemenang dari perlombaan. Tidak adanya transparansi nilailah yang menjadi titik ketidak puasan peserta dari suatu perlombaan tersebut, hanya juri saja yang tahu mengenai nilai poin dan 
tidak menutup kemungkinan ketidakpuasan peserta terhadap poin nilai jika pengambilan keputusan dilakukan secara subjektif. Untuk menghindari hal tersebut, maka diperlukan sistem terkomputasi yaitu SPK atau system pendukung keputusan yang mampu memecahkan permasalahan tersebut. Sistem pendukung keputusan menentukan lovebird unggul dalam perlombaan akan mampu mengatasi masalah tersebut dengan menyesuaikan kriteria dan bobot keputusan apa yang akan diambil, karena konsepnya sederhana dan mudah di pahami, komputasinya efisien, serta memiliki kemampuan mengukur kinerja relatif dari alternatif - alternatif keputusan[2].

Tujuan dari sistem pendukung keputusan adalah sebagai berikut:

a. Membantu manajer dalam pengambilan keputusan atas masalah semi terstruktur

b. Memberikan dukungan atas pertimbangan manajer dan bukannya dimaksudkan untuk menggantikan fungsi manajer.

c. Meningkatkan efektivitas keputusan yang diambil manajer lebih dari pada perbaikan efisiensinya.

d. Kecepatan komputasi. Komputer memungkinkan para pengambil keputusan untuk melakukan banyak komputai secara cepat dengan biaya yang rendah

\section{DASAR TEORI}

\subsection{Sistem Pendukung Keputusan}

Sistem Pendukung Keputusan merupakan adalah sistem yang terkomputasi digunakan untuk pengambilan keputusan yang menyediakan dukungan informasi interaktif. Sistem model yang digunakan adalah analitis, database, penilaian dan pandangan pembuat keputusan dan proses pemodelan berbasis komputer guna mendukung pengambilan keputusan yang semi terstruktur [4]. Sistem ini digunakan untuk membantu pengambilan keputusan pada situasi semi terstruktur dan situasi yang tidak terstruktur[3].

SPK sebagai system memiliki lima karakteristik utama yaitu [5]:

a. Sistem berbasis computer

b. Dipergunakan untuk membantu para pengambil keputusan

c. Untuk memecahkan masalah masalah rumit yang mutahil dilakukan dengan kalkulasi manual

d. Melalui cara simulasi interaktif

e. Data dan model analisis sebagai komponen utama

Dalam SPK terdapat tiga komponen besar yaitu database management, model base dan user interface:
a. Management Database
b. Model Base
c. User Infertace

\subsection{AHP}

Metode AHP dikembangakan oleh Dr. Thomas
L. Saaty dari Wharton School of Bussiness pada tahun 1970-an untuk mengorganisasikan informasi dan judgement dalam memilih alternatif yang disukai. Peralatan utama AHP merupakan hierarki fungsional dengan inputan sebuah persepsi manusia. Selain itu, dasar dari AHP adalah matriks pairwise comparison (matriks perbandingan berpasang - pasangan) untuk menghasilkan bobot relatif antar kriteria maupun alternatif. Suatu kriteria akan dibandingkan dengan kriteria lainnya dalam hal seberapa penting terhadap pencapaian tujuan.

\subsection{TOPSIS}

Proses pengambilan keputusan adalah memilih suatu alternatif. TOPSIS didasarkan pada konsep dimana alternatif terpilih yang terbaik tidak hanya memiliki jarak terpendek dari solusi ideal positif $\left(A^{+}\right)$, namun juga memiliki jarak terpanjang dari solusi ideal negatif $\left(A^{-}\right)[1]$. Konsep ini bisa di terapkan pada beberapa model Multi-Attribute Decision Making (MADM) untuk menyelesaikan permasalahan keputusan. Karena konsepnya sederhana, mudah dipahami, komputasi yang efisien dan memiliki kelebihan mengukur kinerja relatif dari alternatifalternatif keputusan dalam bentuk sistematis yang sederhana. TOPSIS membutuhkan nilai kinerja setiap alternatif $A_{\mathrm{i}}$ pada setiap kriteria $\mathrm{Cj}$ yang ternormalisasi, yaitu :

$$
x_{i j}=\frac{x_{i j}}{\sqrt{\sum_{i-1}^{x_{i j}^{2}}}} .
$$

Dengan $\mathrm{i}=1,2, \ldots, \mathrm{m}$; dan $\mathrm{j}=1,2, \ldots, \mathrm{n}$

Solusi ideal positif $A^{+}$dan solusi ideal negatif $A^{-}$dapat ditentukan berdasarkan rating bobot ternormalisasi $\left(y_{i j}\right)$ sebagai :

$$
\begin{aligned}
& y_{i j}=x_{i} x_{i j}^{s} \text {, } \\
& \text { Dengan } \mathrm{i}=1,2, \ldots, \mathrm{m} ; \text { dan } \mathrm{j}=1,2, \ldots, \mathrm{n}
\end{aligned}
$$

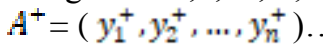

$$
\begin{aligned}
& A^{-}=\left(y_{1}^{-} \times y_{2}^{-}, \ldots y_{n}^{-}\right) \text {. } \\
& \text { Dengan } \\
& y_{j}^{+}=\left\{\begin{array}{c}
\max _{\mathrm{j}_{\mathrm{j}}}, \mathrm{jikaj} \text { adalah atribut keuntungan } \\
\min _{\mathrm{i}} \mathrm{j}_{\mathrm{ij}} \mathrm{j} \mathrm{jka} \mathrm{j} \text { adalah atribut biaya }
\end{array}\right. \\
& y_{j}^{-}=\left\{\begin{array}{c}
\min _{\mathrm{i}} \mathrm{j}_{\mathrm{ij}}, \overline{\mathrm{j}} \mathrm{ka} \mathrm{j} \text { adalah atribut keuntungan } \\
\max _{\mathrm{j}_{\mathrm{ij}}} \overline{\mathrm{j}} \mathrm{ika} \mathrm{j} \text { adalah atribut biaya }
\end{array}\right. \\
& \mathrm{j}=1,2, \ldots, \mathrm{n}
\end{aligned}
$$
positif dirumuskan sebagai:

$$
D_{i}^{+}=\sqrt{\sum_{j=1}^{n}\left({y_{i}^{+}}^{+}-y_{i j}\right)^{2}} \ldots
$$

$$
\text { Dengan } \mathrm{i}=1,2, \ldots, \mathrm{m}
$$

Jarak antara alternatif $A_{\mathbb{i}}$ dengan solusi ideal negatif dirumuskan sebagai:

$$
D_{i}^{-}=\sqrt{\sum_{j=1}^{n}\left(Y_{i j}-y_{i}^{-}\right)^{2}}
$$

Dengan $\mathrm{i}=1,2, \ldots, \mathrm{m}$ 
Nilai prefensi untuk setiap alternatif $\left(V_{i}\right)$ diberikan sebagai:

$$
V_{i} \frac{D_{i}}{D_{i}^{-}+D_{i}^{+}}
$$

$$
\text { Dengan } \mathrm{i}=1,2, \ldots, \mathrm{m}
$$

Nilai $V_{i}$ yang lebih besar menunjukkan bahwa alternatif $A_{i}$ lebih dipilih.

\section{METODOLOGI PENELITIAN}

Metode penelitian yang digunakan adalah metode prototype. Prototype Model adalah salah satu metode pengembangan perangkat lunak yang banyak digunakan. Dengan metode ini pembuat program dan client bisa berinteraksi selama proses pembuatan sistem berlangsung. Proses kegiatan yang ada pada metode prototyping bisa dijelaskan sebagai berikut:

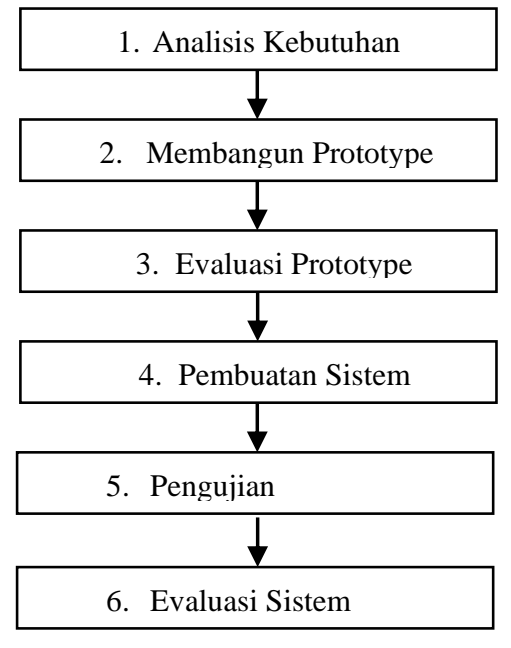

Gambar 1. Alur Sistem Pada Tahap Prototype

\section{ANALISA}

4.1 Sistem yang dirancang dan dibangun dalam penelitian ini adalah Sistem Pendukung Keputusan Menentukan Lovebird Unggul dalam Perlombaan Menggunakan Metode AHP-TOPSIS (Studi Kasus: Komunitas Lovebird Indonesia-Wilayah Tuban. Alur Menentukan Lovebird Unggul dalam Perlombaan adalah sebagai berikut:

a. Komunitas membuat event lomba.

b. Panitia atau admin melakukan pendaftaran peserta.

c. Lalu Juri melakukan penilaian sesuai dengan kriteria.

a. Peserta lomba akan diseleksi kemudian akan di urutkan berdasarkan nilai perhitungan tertinggi

b. Setelah juri mendapatkan nilai peserta yang tertinggi, Panitia akan mencetak hasil tersebut sebagai hasil sah dari perlombaan.

\subsection{Sumber Data}

Data diperlukan untuk menghasilkan informasi yang baik,karena informasi pada dasarnya merupakan hasil pengolahan data yang diinputkan pada sistem. Pada penelitian ini sumber data berasal dari data internal, yakni data yang berasal dari Komunitas Lovebird Indonesia-Wilayah Tuban untuk mendukung penelitian ini adalah data internal. Data internal yang berasal dari tempat studi kasus untuk mendukung penelitian ini. Adapun beberapa data internal yang dibutuhkan adalah bentuk kepala, bentuk dada, kontras warna burung, kondisi burung, ukuran burung, tingkah laku, bentuk punggung, bentuk sayap, harmonisasi, dan durasi bunyi burung.

\subsection{Pengujian Hasil}

Hasil perbandingan perhitungan manual dan perhitungan sistem dalam penentuan bobot dapat

\begin{tabular}{|c|c|c|c|}
\hline No. & Kriteria & $\begin{array}{c}\text { Hasil } \\
\text { Perhitungan } \\
\text { Manual }\end{array}$ & $\begin{array}{c}\text { Hasil SPK } \\
\text { AHP }\end{array}$ \\
\hline 1. & Bentuk kepala & 0.820404 & 0.8206 \\
\hline 2. & Bentuk dada & 0.672836 & 0.673 \\
\hline 3. & Kontras warna & 1.077875 & 1.078 \\
\hline 4. & Kondisi burung & 0.723911 & 0.7239 \\
\hline 5. & Ukuran burung & 0.675834 & 0.6756 \\
\hline 6. & Tingkah laku & 1.589112 & 1.5892 \\
\hline 7. & $\begin{array}{l}\text { Bentuk } \\
\text { punggung }\end{array}$ & 1.040576 & 1.0406 \\
\hline 8. & Bentuk sayap & 0.710811 & 0.7109 \\
\hline 9. & Harmonisasi & 2.533613 & 2.5341 \\
\hline 10. & Durasi Bunyi & 0.155028 & 0.155 \\
\hline
\end{tabular}
di lihat dari tabel berikut :

Hasil perbandingan perhitungan manual dan perhitungan sistem dalam seleksi kandidat dapat dilihat dari tabel berikut:

Tabel 2. Hasil Perbandingan Perhitungan Seleksi Kandidat TOPSIS

\begin{tabular}{clll}
\hline No. & Nama & $\begin{array}{l}\text { Nilai } \\
\text { Manual }\end{array}$ & $\begin{array}{l}\text { Nilai } \\
\text { Sistem }\end{array}$ \\
\hline 1. & King & 0.593016 & 0.592 \\
2. & Arthur & 0.465299 & 0.454 \\
3. & Adele & 0.513174 & 0.498 \\
4. & Turqoise & 0.405015 & 0.414 \\
5. & Epson & 0.478994 & 0.472 \\
\hline
\end{tabular}

\subsection{Pembahasan}

Berdasarkan tabel perbandingan hasil pengujian pada Tabel 4.3 di dapatkan akurasi pemenang peserta pada suatu perlombaan antara pengujian perhitungan manual dengan pengujian sistem adalah 98\%. Dengan adanya adanya sistem pendukung keputusan menentukan lovebird unggul dalam perlombaan menggunakan metode AHPTOPSIS dapat mengurangi kesalahan dalam perhitungan dan mempersingkat waktu dalam proses penjurian. Selain itu dengan adanya sistem 
ini, maka hasil dari perlombaan dapat langsung di lihat oleh peserta melalui layar LCD.

Untuk login sebagai juri, user akan diminta untuk memasukkan username dan passwod. Pada halaman juri terdapat 4 menu utama yaitu: Event, Peserta, Seleksi. Pada sub menu List Event terdapat informasi event lomba yang berisi tanggal perlombaan, Kategori yang di lombakan, status dari lomba tersebut, dan aksi. Dalam kolom aksi admin dapat menekan tombol "Hasil Seleksi" untuk melihat pemenang dari salah satu perlombaan.

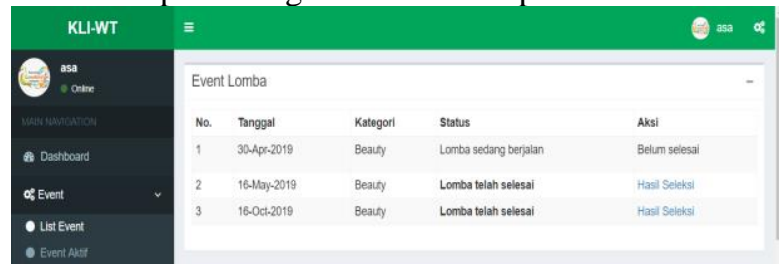

Gambar 2. Halaman List Event Juri

Gambar 3. adalah halaman event lomba aktif juri. Juri dapat melihat event yang aktif, kategori perlombaan yang aktif, dan nama juri yang memegang perlombaan.

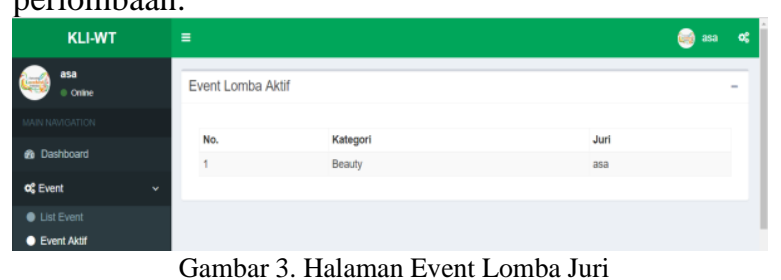

Gambar 4. adalah halaman menu dari penilaian peserta. Halaman ini terdapat informasi berupa tampilan nama perserta, kategori perlombaan, nama burung, nama pemilik burung dan alamat pemilik burung. Juri dapat memberikan penilaian dengan menekan tombol "Berikan Nilai" pada kolom aksi.

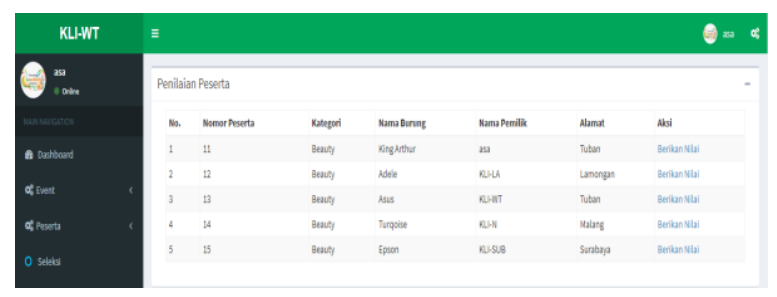

Gambar 4. Menu Peserta

Gambar 5. adalah lanjutan dari gambar 4. Didalam menu peserta terdapat informasi berupa penilaian dari 10 kriteria. Juri akan mengisi nilai berupa angka di dalam field sesuai dengan indikator penilaian.

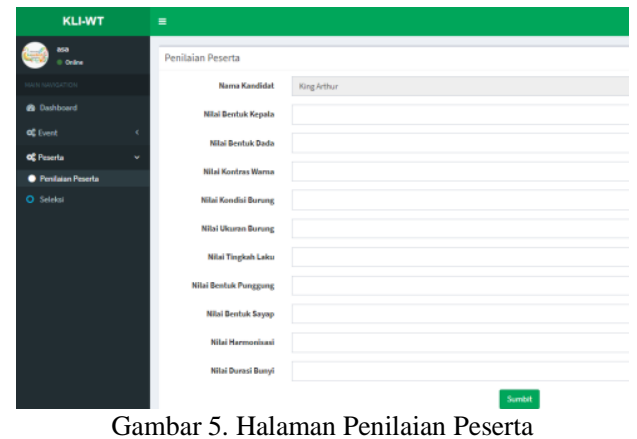

Gambar 6 adalah gambar dari menu seleksi. Didalam menu seleksi terdapat informasi berupa nama peserta,nilai peserta, dan bobot dari kategori perlombaan. Untuk melakukan perankingan juri akan menekan tombol "Hitung Topsis".

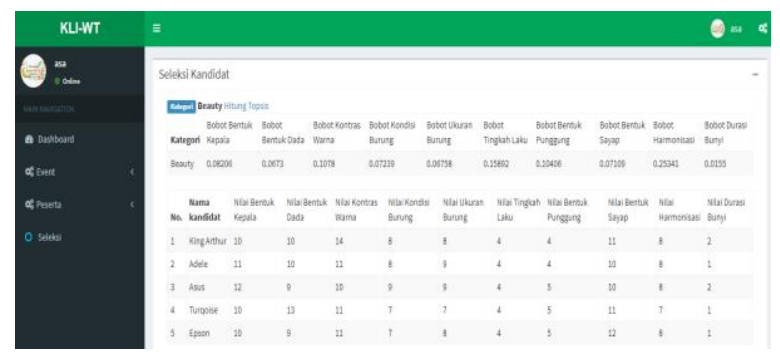

Gambar 6. Menu Seleksi

Gambar 7 adalah proses perankingan atau proses perhitungan TOPSIS yang terbagi menjadi 5 tahap. Tahap pertama di bagi menjadi 3 langkah. Langkah pertama adalah memangkatkan dari nilai yang sudah di input oleh juri. Langkah kedua adalah menjumlahkan tiap kolom tiap-tiap kriteria. Langkah ketiga adalah dari jumlah dari langkah kedua hasil tersebut di akarkan.

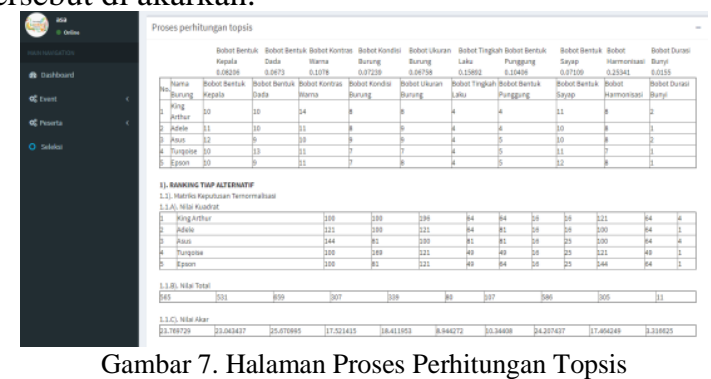

Gambar 8 adalah Tahap kedua dari proses perhitungan TOPSIS. Tahap kedua ini di bagi menjadi 2 langkah. Langkah pertama adalah membagi nilai kriteria dengan nilai akar. Langkah kedua adalah hasil dari akar di kali dengan nilai bobot.

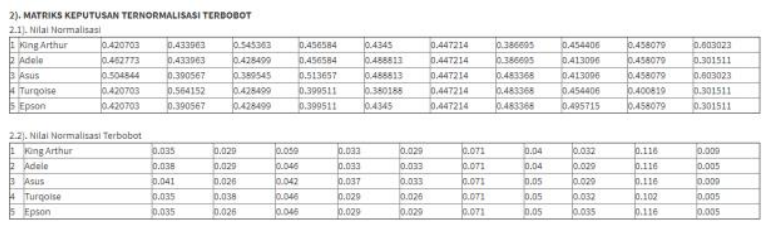

Gambar 8. Halaman Proses Perhitungn TOPSIS

Gambar 9 adalah tahap ketiga yaitu mencari matriks solusi ideal positif dan matriks solusi ideal negatif.

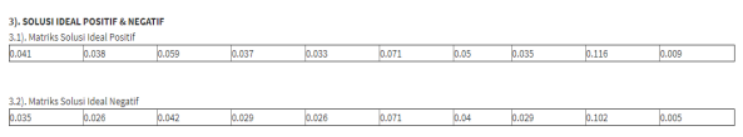

Gambar 9. Halaman Solusi Ideal Positif Dan Negatif

Gambar 10 adalah proses jarak dengan solusi ideal positif dan negatif. Didalam proses jarak dengan solusi ideal di bagi menjadi dua langkah. Langkah pertama dari hasil gambar 9 (Maktriks Ideal Positif) nilai tersebut di kuadratkan, di jumlah tiap barisnya dan di akar (D+). Langkah kedua dari hasil gambar 9 
(Matriks Ideal Negatif) nilai tersebut di kuadratkan, di jumlah tiap barisnya, dan di akar (D-).

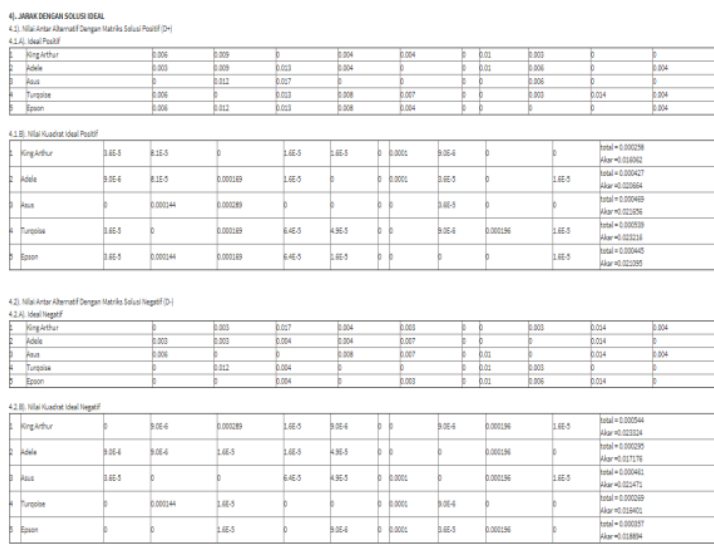

Gambar 10. Halaman Jarak Dengan Solusi Ideal

Gambar 11 adalah proses nilai preferensi untuk setiap alternatif. Dalam proses menghitungan preferensi setiap alternative di bagi menjadi dua langkah. Langkah pertama adalah menjumlahkan nilai D+ (gambar 9) dengan D-. Langkah kedua adalah hasil akar dari D- akan di bagi dengan hasil nilai dari D+ dan D-.

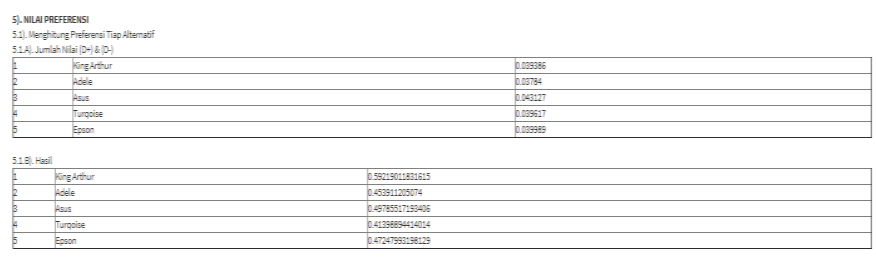

Gambar 11. Halaman Nilai Preferensi

4.5 Pengujian Pakar

Tahap pengujian pakar dilakukan oleh juri dengan mencocokan hasil keluaran pada sistem dan hasil manual untuk mengetahui seberapa banyak kecocokan antara keluaran data. Pengujian penentuan lovebird unggul dalam perlombaan dilakukan sebanyak 5 kali pengujian dengan data yang berbeda. Dari 5 kali percobaan tersebut di buat tabel berisi nomor peserta, nama burung, nilai dari penjumlahan dari tiap kriteria, dan ranking.

Tabel 3. Pengujian 1

\begin{tabular}{ccccccc}
\hline $\begin{array}{c}\text { Uji } \\
\text { ke- }\end{array}$ & $\begin{array}{l}\mathrm{N} \\
\mathrm{o}\end{array}$ & Nama & $\begin{array}{c}\text { Nilai } \\
\text { Manual }\end{array}$ & $\begin{array}{c}\text { Ranking } \\
\text { (Manual) }\end{array}$ & $\begin{array}{l}\text { Nilai } \\
\text { Sistem }\end{array}$ & $\begin{array}{c}\text { Rank } \\
\text { ing } \\
\text { (Sist } \\
\text { em) }\end{array}$ \\
\hline 1. & 1 & Roy & 81 & 2 & 0.691 & 2 \\
\cline { 2 - 7 } & 2 & Klaten & 63 & 4 & 0.346 & 4 \\
\cline { 2 - 7 } & 3 & Birawa & 89 & 1 & 1.000 & 1 \\
\cline { 2 - 7 } & 4 & Varan & 74 & 3 & 0.527 & 3 \\
\hline 5 & Rakic & 60 & 5 & 0.074 & 5 \\
\hline
\end{tabular}

Tabel 4. Pengujian 2

\begin{tabular}{|c|c|c|c|c|c|c|}
\hline $\begin{array}{l}\text { Uji } \\
\text { ke- }\end{array}$ & No & Nama & $\begin{array}{c}\text { Nilai } \\
\text { Manual }\end{array}$ & $\begin{array}{l}\text { Rankin } \\
\text { g } \\
\text { (Manu } \\
\text { al) }\end{array}$ & $\begin{array}{l}\text { Nilai } \\
\text { Siste } \\
\mathrm{m}\end{array}$ & $\begin{array}{l}\text { Ranking } \\
\text { (Sistem) }\end{array}$ \\
\hline \multirow[t]{5}{*}{2.} & 1 & Bima & 92 & 1 & $\begin{array}{c}1.00 \\
0\end{array}$ & 1 \\
\hline & 2 & $\mathrm{Az}-\mathrm{S}$ & 80 & 2 & $\begin{array}{c}0.60 \\
8\end{array}$ & 2 \\
\hline & 3 & Super & 71 & 3 & $\begin{array}{c}0.31 \\
5\end{array}$ & 3 \\
\hline & 4 & Raka & 60 & 5 & $\begin{array}{c}0.06 \\
1\end{array}$ & 5 \\
\hline & 5 & Beauty & 63 & 4 & $\begin{array}{c}0.16 \\
3\end{array}$ & 4 \\
\hline
\end{tabular}

\section{KESIMPULAN}

Berdasarkan penelitian yang dilaksanakan oleh penulis pada sistem pendukung keputusan menentukan lovebird unggul dalam perlombaan dengan metode AHP-TOPSIS, dapat ditarik kesimpulan sebagai berikut:

1. Dengan adanya sistem pendukung keputusan menentukan lovebird unggul dalam perlombaan dengan metode AHP-TOPSIS peserta bisa lebih melihat transparansi nilai pada saat perlombaan, karena penilaian tersebut di tampilkan pada layar LCD yang dapat di lihat oleh seluruh peserta lomba.

2. Dengan sistem pendukung keputusan menentukan lovebird unggul dalam perlombaan dengan metode AHP-TOPSIS ini telah berhasil dalam membantu juri dalam menentukan pemenang dalam suatu kagetori perlombaan secara akurat dan objektif, dibuktikan dengan hasil pengujian menunjukkan bahwa 5 data uji data rill $(98 \%)$ telah menunjukkan hasil yang seimbang antara keputusan sistem dengan keputusan manual.

3. Dengan adanya sistem pendukung keputusan menentukan lovebird unggul dalam perlombaan menggunakan AHP-TOPSIS ini telah berhasil mengurangi kesalahan dalam perhitungan poin dan menambah keefektifitasan waktu dalam penilaian, hal ini di buktikan dalam 5 kali pengujian pada juri.

\section{REFERENCES}

[1] Alamsyah, Muhmmad Nur. 2017. Implementasi Metode TOPSIS Dalam Memprediksi Tingkat Kelulusan Mahasiswa Di STMIK MURA. JTI, Vol 9 No.2, Desember 2017. STMIK MUSIRAWAS Lubuk Kupang.

[2] Faradillah, Yanty, dkk. 2019. Model Sistem Pendukung Keputusan (SPK) Tingkat Kepuasan Konsumen Transportasi Online. JITEKH, Vol 7, No 1, Tahun 2019, 7-14, ISSN 23385677, ISSN 2549-6646 Online. Fakultas Teknik Informatika STMIK Harapan Ibu Aceh.

[3] Na'am, Jufriadif. 2017. Sebuah Tinjauan Penggunaan Metode Analytic Hierarchy Process (AHP) Dalam Sistem Penunjang Keputusan (SPK) Pada Jurnal Bahasa Indonesia. Mediasisfo vol. 11, No 2, Oktober 2017. Universitas Putra Indonesia YPTK Padang. 
[4] Siswanto, Edi, dkk. 2018. Penentuan Kelayakan Kandang Sapi Menggunakan AHP-TOPSIS (Studi Kasus: UPT Pembibitan Ternak dan Hijauan Makanan Ternak Singosari). Jurnal Pengembangan Teknologi Informasi dan Ilmu Komputer vol. 2, No. 12, Desember 2018, hlm. 6322-6330, eISSN: 2548-964X. Fakultas Ilmu Komputer Universitas Brawijaya.
[5] Wisanti, Widya. 2017. Sistem Penunjang Keputusan Penerimaan Guru Berbasis Web. Jural Instek Vol 2, No 2, April 2017. Jurusan Elektro Universitas Sawerigading Makassar 